\title{
STRATEGI PENGEMBANGAN PRODUK KERUPUK KEMPLANG DENGAN METODE SWOT DI UMKM DUA PUTRI BUMI WARAS KOTA BANDAR LAMPUNG
}

\author{
Peri Daya Pratama ${ }^{1 *}$, Burhan Nudin ${ }^{2}$ \\ Progam Studi Teknik Industri Fakultas Teknik \\ Universitas Tulang Bawang Lampung \\ Jl. Gajah Mada No. 34 Kotabaru Bandar Lampung \\ *Penulis Korespondensi: peridaya22@gmail.com
}

\begin{abstract}
The strategy of developing kemplang cracker products in Dua Putri UMKM sub-district of Bumi Waras, Bandar Lampung city is experiencing a high level of competition, the aim of this research is to produce a strategy that is in accordance with the conditions of the Dua Putri UMKM in developing a business, and to provide strategic input from the results of the research. Data collection techniques in this study were carried out by observation, interviews and questionnaires then analysed by SWOT. It is known that the IFAS value is 3,36080 with a strength factor having a value of 2.51632 and a weakness of 0.84448 with a difference in value (+) of 1.67184. and the EFAS value is 2.82229 with the opportunity factor having a value of 2.30108 and the threat factor 0.52121 with the difference in value (+) 1.77987. This value indicates that the organization is experiencing a period of growth both in sales, taste, and price differences. UMKM two putri kemplang crackers are on average in her quest to pursue a strategy of exploiting strengths to overcome weaknesses. From the results of the Cartecius diagram, that kemplang cracker Dua Putri UMKM are in quadrant 1 (one), namely an aggressive strategy, where this UMKM is in a very favorable position, this UMKM has the opportunity and strength so that it can take advantage of the existing opportunities
\end{abstract}

Keywords: EFAS, IFAS, Kemplang Crakers, SWOT Analysis, Strategy

\section{Pendahuluan}

Usaha Mikro Kecil Menengah (UMKM) merupakan salah satu bagian penting adri perekonomian negar yang sedang berkembang, meskipun Usaha Mikro Kecil menengah sering dianggap berkonotasi tradisional dan memiliki skal yang kecil baik dalam jumlah karyawn, aset, omset serta modal yang rendah. Jumlah UMKM yang cukup besar memuat peranan UMKM dalam menunjang perekonomian dan menyerap tenaga kerja yang cukup tinggi. Undang-Undang nomor 20 Tahun 2008 usaha mikro adalah usaha produktif milik orang perorangan ataupun badan usaha perorangan dengan jumlah asset maksimal 0 sampai Rp 50 juta dan omzet total 0 sampai 300 juta. Usaha kecil adalah usaha ekonomi produktif yang berdiri sendiri dilakukan oleh orang perorangan ataupun badan usaha akan tetapi bukan merupakan anak perusahaan dengan jumlah asset lebih dari Rp 50 juta sampai Rp 500 juta dan omzet total $\mathrm{Rp} 300$ juta sampai Rp 2,5 milyar. Usaha menengah adalah usaha ekonomi produktif yang berdiri sendiri dilakukan oleh cabang orang perseorangan atau badan usaha yang bukan merupakan anak perusahaan dengan jumlah kekayaan bersih lebih dari $\mathrm{Rp}$ 500 juta sampai Rp 10 milyar dan omzet total Rp 2,5 milyar sampai Rp 50 milyar.

Berbagai sektor perekonomian terus dipacu untuk mendorong perekonomian Indonesia. Salah satu yang diharapkan terus berkembang adalah UMKM. UMKM dalam perekonomian Indonesia memegang peranan yang sangat penting. UMKM dapat bertahan dalam kondisi krisis ekonomi, menjadi penggerak ekonomi nasional dalam mendatangkan devisa.. Kota Bandar Lampung memiliki potensi sumber daya dan posisi strategis sebagai pintu gerbang menuju pulau sumatera serta lalu lintas komoditi dari Sumatera ke Jawa atau sebaliknya yang melalui provinsi Lampung, sehingga memungkinkan bisnis dapat berkembang sangat dinamis. Usaha Mikro Kecil Menengah yang memproduksi produk kerupuk kemplang yang terletak di 
Kecamatan Bumi Waras Kota Bandar Lampung Provinsi Lampung. UMKM kerupuk kemplang dua putri menghadapi banyak kendala terutama dalam mempertahankan dan mengembangkan usahanya. Kendala yang dihadapi antara lain tingginya tingkat persaingan kerupuk kemplang dua putri terutama kalah bersaing dengan perusahaan besar, kesulitan dalam pemasaran karena kurangnya tenaga pemasaran, Berikut gambar Produk Kerupuk Kemplang Dua Putri:

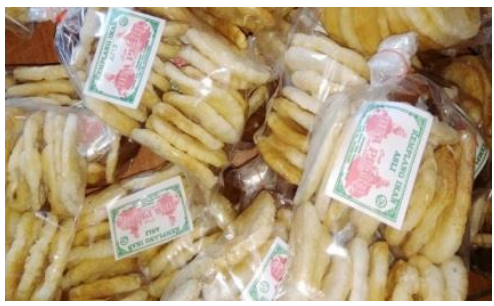

Gambar 1. Produk Kerupuk Kemplang

Sumber : Kerupuk Kemplang UMKM Dua Putri. (2020)

\section{Produk}

Produk merupakan segala sesuatu yang dapat ditawarkan produsen untuk diperhatikan, diminta, dicari, dibeli, digunakan, atau dikonsumsi pasar sebagai pemenuhan kebutuhan atau keinginan pasar yang bersangkutan. Secara konseptual produk adalah pemahaman subyektif dari produsen atas sesuatu yang bisa ditawarkan, sebagai usaha untuk mencapai tujuan organisasi melalui pemenuhan kebutuhan dan keinginan konsumen, sesuai dengan kompetensi dan kapasitas organisasi serta daya beli pasar, Tjiptono (2002).

\section{Pengembangan Produk}

Pengembangan produk dan inovasi merupakan sebuah hal penting yang dibutuhkan perusahaan. Adanya pesaing diluar perusahaan menjadi satu alasan perusahaan tersebut didirikan. Maka dari itu, proses ini penting agar perusahaan mempunyai produk yang berbeda dengan pesaing dan memiliki keunggulan yang menonjol, sehingga membuat orang tertarik dengan produknya.

Kotler dan Amstrong (2008), menjelaskan pengembangan produk adalah mengembangkan konsep produk menjadi produk nyata untuk dapat di ubah menjadi produk yang bisa dikerjakan.
Pengembangan produk merupakan strategi pemasaran yang memerlukan penciptaan produk baru yang dapat dipasarkan, proses merubah aplikasi untuk teknologi baru ke dalam produk yang dapat dipasarkan. Pengertian pengembangan produk meliputi:

1. Produk baru, yaitu:

a. Produk yang benar-benar inovatif dan unik

b. Produk pengganti yang berbeda dari produk yang sudah ada

c. Produk imitative, yaitu produk yang baru bagi perusahaan tertentu tetapi bukan baru di dalam pasar

d. Produk yang menggunakan bahan baku baru sama sekali

2. Pengembangan produk:
a. Riset pemasaran
b. Rekayasa
c. Desain

3. Modifikasi produk, yaitu memperbaiki produk yang sudah ada yang meliputi kualitas, fitur, dan style yang tujuannya meningkatkan penjualan. Modifikasi produk menciptakan tiga dimensi, yaitu:
a. Perbaikan mutu (quality improvement)
b. Perbaikan ciri-ciri khusus (feature improvement)
c. Perbaikan gaya (style improvement)

4. Merchandising, yaitu semua aktivitas perencanaan baik dari produsen maupun pedagang yang dimaksudkan untuk menyesuaikan antara produk-produk yang dihasilkan dengan permintaan pasar.

Dari penjabaran di atas maka kesimpulan yang didapat yakni pengembangan produk adalah proses perubahan yang dilakukan terhadap produk yang sudah ada sekaligus proses pencarian inovasi untuk menambah nilai terhadap 
barang lama dengan mengkonversikannya ke dalam produk tersebut.

\section{Tahap-Tahap Pengembangan Produk}

Menurut Philip Kotler (2007), tahap-tahap pengembangan produk terdiri dari :

a. Tahap Penyaringan

Tahap Penyaringan dilakukan setelah berbagai macam ide tentang produk telah tersedia. Dalam tahap ini merupakan pemilihan sejumlah ide dari berbagai macam sumber Adapun informasi atau ide berasal dari manager perusahaan, pesaing, para ahli termasuk konsultan, para penyalur, langganan, atau lembaga lain.

b. Tahap Analisa Bisnis

Pada tahap ini msing-masing ide dianalisa dari segi bisnis untuk mengetahui seberapa jauh kemampuan ide tersebut dapat menghasilkan laba.

c. Tahap Pengembangan

Pada tahap ini, ide-ide yang telah dianalisa perlu dikembangkan karena ide-ide tersebut dianggap lebih menguntungkan. Pengembangan ini tentunya harus sesuai dengan kemampuan perusahaan.

d. Tahap Pengujian

Tahap pengujian merupakan kelanjutan dari tahap pengembangan, meliputi:

1. Pengujian tentang konsep produk

2. Pengujian terhadap kesukaan konsumen

3. Penelitian laboratorium

4. Test penggunaan

5. Operasi pabrik percontohan

6. Tahap Komersialisasi

Tahap ini merupakan tahap terakhir dari rangkaian pengembangan produk baru. Pada tahap ini semua fasilitas telah disiapkan baik itu fasilitas produksi maupun fasilitas pemasaran. Semua kegiatan harus saling bekerja sama meskipun mempunyai tujuan berbeda.

\section{Beberapa faktor-faktor yang mempengaruhi pengembangan produk}

Menurut Swastha (1997), faktor-faktor yang mempengaruhi pengembangan produk terdiri dari :

1. Tidak stabilnya posisi persaingan

Dengan semakin banyaknya produk sejenis yang ditawarkan maka situasi persaingan semakin tajam, apalagi para pengusaha sejenis yang telah memperbaiki produk untuk lebih disesuaikan.

2. Munculnya persaingan

Suatu barang yang terjual dengan baik di pasaran dan dapat menghasilkan keuntungan, akan mendorong pengusaha lain untuk memproduksi barang yang sedang laku tersebut bahkan dengan kualitas yang lebih baik.

3. Banyaknya variasi penggunaan barang

Dengan makin banyaknya variasi penggunaan suatu produk maka hal ini akan mendorong perusahaan untuk mengembangkan hasil produksinya, sehingga produk tersebut akan mempunyai bermacam-macam kegunaan.

4. Pemanfaatan kapasitas produksi yang efektif

Faktor lain melaksanakan pengembangan produk adalah memanfaatkan kapasitas produksi, karena pada umumnya perusahaan belum berproduksi pada kapasitas penuh.

Menurut George (1993), faktor eksternal yang kemungkinan besar paling menghambat introduksi produk adalah meningkatnya biaya modal. Sudah jelas bahwa dana yang dikeluarkan untuk membiayai kegagalan adalah uang yang lebih baik dibelanjakan untuk mengembangkan dan memperkenalkan keberhasilan. Mengetahui penyebab kegagalan dapat membantu 
menyaring usaha yang akan gagal sebelum terlanjur mengeluarkan terlalu banyak dana dan waktu. Hal yang sangat bermanfaat untuk melihat bagaimana manajemen menilai beberapa alasan keberhasilan dan kegagalan dalam usaha mencapai sasaran produk baru. Seperti sudah dapat diperkirakan, alasannya adalah serupa, yaitu:

a. Riset pasar yang meramal ataupun tidak.

b. Penjadwalan waktu yang baik atau buruk.

Sedangkan menurut Kotler (1998), faktor-faktor yang turut dalam menghambat pengembangan produk baru adalah:

a. Kekurangan gagasan produk baru yang penting di area tertentu (mungkin hanya tersisa sedikit cara untuk memperbaiki beberapa produk dasar)

b. Pasar yang terbagi-bagi (persaingan ketat menyebabkan pasar terbagibagi). Perusahaan harus mengarahkan produk baru mereka pada sekmen pasar yang lebih kecil, dan hal ini berarti penjualan dan laba yang lebih rendah untuk tiap produk.

c. Kendala sosial dan pemerintah (produk baru harus memenuhi kriteria seperti keamanan dan keseimbangan lingkungan).

d. Mahalnya proses pengembangan produk baru (suatu perusahaan umumnya harus menciptakan banyak gagasan produk baru untuk menemukan hanya satu yang layak dikembangkan).

e. Kekurangan modal (beberapa perusahaan dengan gagasan-gagasan baik tidak dapat mengumpulkan dana yang diperlukan untuk melakukan riset).

f. Waktu pengembangan yang lebih singkat (banyak pesaing mungkin mendapatkan gagasan yang sama pada saat yang sama, dan kemenangan sering diraih oleh yang paling gesit).

g. Siklus produk yang lebih singkat (ketika suatu produk baru berhasil, pesaing dengan cepat menirunya).

\section{Metode Penelitian}

Analisis SWOT

Analisis SWOT Menurut Freddy Rangkuti (2006), Analis swot adalah indentitas berbagai faktor secara sistematis untuk merumuskan strategi perusahan. Analisis ini didasarkan pada logika yang dapat memaksimalkan kekuatan (strenght) dan peluang (opportunity), namun secara bersamaan dapat meminimalkan kelemahan (weakness) dan ancaman (threat). Proses pengambilan keputusan strategis selalu berkaitan dengan pengembangangmisi, tujuuan , dan strategi, dan kebijan dari perusahaan. Dengan demikian perecanaan strategi (strategic planner) harus menganalisi faktor-faktor strategis perusahaan (kekuatan, kelemahan , peluang, dan ancaman) dalam kondisi yang ada disaat ini. Hal ini disebut dengan analisis situasi. Model yang paling popular untuk analisis situasi adalah analisi SWOT. Analisis SWOT membandingkan antar faktor ekternal dan internal. Analisis SWOT:

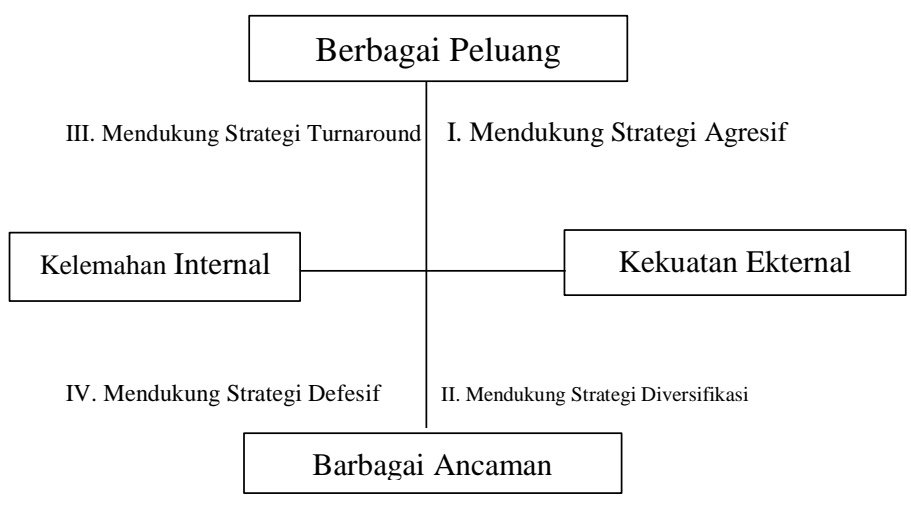

Kuadran 1: $\quad$ Ini merupakan situasi yang sangat menguntungkan. Perusahaan tersebut memiliki peluang dan kekuatan sehingga dapat memanfaatkan peluang yang ada. Startegi yang harus diterapka dalam kondisi ini adalah mndukung kebijakan pertumbuhan yang agresif (Growth oriented strategy)

Kuadran 2: $\quad$ Meskipun menghadapi berbai ancaman, perusahaan ini masih memiliki kekuatan dari segi internal. Strategi yang harus diterapkan adalah yang mengunakan kekuatan untuk 


\begin{abstract}
memanfaatkan peluang jangka panjang dengan cara strategi diversifikasi (produk/pasar).
\end{abstract}

Kuadran 3 : Perusahaan menghadapi peluang pasar yang sangat besar, tetapi dilain pihak, ia menghadapi beberapa kendala/kelamahan internal. Fokus perusahaan ini adalah meminimalkan masalahmasalah internal perusahaan sehingga dapat merebut peluang pasar yang baik.

Kuadran 4: $\quad$ Ini merupakan situasi yang sangat tidak mengguntungkan,

perusahaan tersebut menghadapi berbagai ancaman dan kelemahan internal.

Fungsi dari analisi SWOT adalah untuk mendapatkan informasi dari analisis situasi dan mmisahkannya dalam pokok persoalan internal (kekuatan dan Kelemahan) dan pokok persoalan ekternal (peluang Dan ancaman). Analisis SWOT tersebut akan menjelaskan apakah informasi tersebut berindikasi sesuatu yang akan membantu perusahaan mencapai tujuannya atau memberikan indikasi bahwa terdapat rintangan yang harus dihadapi atau diminimalkan untuk memenuhi pemasukan yang diinginkan, Ferrel dan Harline (2005)

\section{Analisis Data}

Dalam mengidentifikasikan lingkungan internal meliputi kekuatan dan kelemahan dan lingkungan eksternal yang meliputi peluang dan ancaman pada UMKM Kerupuk Kemplang Dua Putri, maka disajikan data-data yang diperoleh mengenai Strategi Pengembangan Produk Kerupuk Kemplang Di UMKM Dua Putri Kelurahan Bmi Rawas Kota Bandar Lampung. Penulis telah melakukan wawancara langsung dengan pihak-pihak yang terkait dengan penelitian ini.

\section{Pengolahan Data}

Dalam menentukan suatu strategi dalam analisis SWOT terlebih dahulu menghitung Hasil IFAS dan EFAS, berikut hasil pengolahan data dari Strategi Pengembangan Produk Kerupuk Kemplang Di UMKM Dua Putri Kelurahan Bumi Waras Kota Bandar Lampung.

\section{Matriks IFAS (Internal factor Analysis Summary)}

Dalam matriks IFAS ini, data yang diperoleh adalah data yang berasal dari tabel hasil kuesioner penilaian bobot dan penilaian skor pada Faktor Internal pada UMKM Kerupuk Kemplang Dua Putri Kecamatan Bumi Wras Kota Bandar Lampung.

Tabel 1 Hasil Matriks IFAS

\begin{tabular}{|c|c|c|c|}
\hline Faktor-Faktor Internal & Bobot & Rating & $\begin{array}{l}\text { Bobot X } \\
\text { Rating }\end{array}$ \\
\hline \multicolumn{4}{|l|}{ Kekuatan } \\
\hline $\begin{array}{l}\text { Produk Kerupuk Kemplang Dijual } \\
\text { Berkualias Dari Segi Rasa }\end{array}$ & $\begin{array}{l}0,149 \\
09\end{array}$ & 4 & 0,59636 \\
\hline $\begin{array}{l}\text { Harga Kerupuk Kemplang Lebih } \\
\text { Murah Dari Pesaing }\end{array}$ & $\begin{array}{l}0,163 \\
63\end{array}$ & 4 & 0,65452 \\
\hline $\begin{array}{l}\text { Hubungan Yang Harmonis Antara } \\
\text { Pemilik Dengan Karyawan }\end{array}$ & $\begin{array}{l}0,156 \\
36\end{array}$ & 4 & 0,62544 \\
\hline $\begin{array}{l}\text { Mempunyai Tenaga Kerja Yang } \\
\text { Cukup Banyak Dan Berpengalaman }\end{array}$ & 0,16 & 4 & 0,64 \\
\hline Total Kekuatan & $63 \%$ & & 2,51632 \\
\hline \multicolumn{4}{|l|}{ Kelemahan } \\
\hline $\begin{array}{l}\text { Manajemen Keuangan Masih } \\
\text { Konvensional }\end{array}$ & $\begin{array}{l}0,101 \\
81\end{array}$ & 3 & 0,30543 \\
\hline $\begin{array}{l}\text { Sempitnya Tempat Produksi Dan } \\
\text { Pengepakan }\end{array}$ & $\begin{array}{l}0,094 \\
54\end{array}$ & 2 & 0,18908 \\
\hline Teknik Produksi Masih Manual & $\begin{array}{l}0,087 \\
27\end{array}$ & 2 & 0,17454 \\
\hline $\begin{array}{l}\text { Jadwal Pengiriman Produk Tidak } \\
\text { Menentu }\end{array}$ & $\begin{array}{l}0,087 \\
27\end{array}$ & 2 & 0,17454 \\
\hline Total Kelemahan & $37 \%$ & & 0,84448 \\
\hline Total IFAS & $\mathbf{1 , 0 0}$ & & 3,36080 \\
\hline
\end{tabular}

Berdasarkan data diatas bahwa nilai kekuatan adalah nilai tertinngi untuk matriks IFAS dengan jumlah 2,51632 dibandingkan dengan faktor kelemahan adalah 0,84448 , maka nilai yang dapat dijadikan dasar kebijakan adalah nilai kekuatan.

\section{Matriks EFAS (Eksternal factor Analysis Summary)}

Dalam matriks EFAS ini, data yang diperoleh adalah data yang berasal dari tabel hasil kuesioner penilaian bobot dan penilaian skor pada Faktor Eksternal pada UMKM Kerupuk Kemplang Dua Putri Kecamatan Bumi Wras Kota Bandar Lampung. 
Tabel 2. Hasil Matriks EFAS

\begin{tabular}{|c|c|c|c|}
\hline $\begin{array}{l}\text { Faktor-Faktor } \\
\text { Eksternal }\end{array}$ & Bobot & Rating & $\begin{array}{l}\text { Bobot } \mathbf{X} \\
\text { Rating }\end{array}$ \\
\hline \multicolumn{4}{|l|}{ Peluang } \\
\hline $\begin{array}{lr}\text { Produk } & \text { sudah } \\
\text { masuk } & \text { pasar }\end{array}$ & 0,17374 & 3 & 0,52122 \\
\hline $\begin{array}{lr}\text { Gaya } & \text { hidup } \\
\text { masyarakat yang } \\
\text { suka makan kerupuk }\end{array}$ & 0,18146 & 3 & 0,54438 \\
\hline $\begin{array}{lr}\text { Adanya } & \text { dukungan } \\
\text { beruoa } & \text { pelatihan } \\
\text { dari } & \text { pihak }\end{array}$ & 0,16988 & 3 & 0,50964 \\
\hline $\begin{array}{l}\text { Lokasi mudah } \\
\text { diakses }\end{array}$ & 0,18146 & 4 & 0,72584 \\
\hline Total Peluang & $70 \%$ & & 2,30108 \\
\hline \multicolumn{4}{|l|}{ Ancaman } \\
\hline $\begin{array}{l}\text { Tidak stabilnya } \\
\text { harga bahan baku }\end{array}$ & 0,07722 & 2 & 0,15444 \\
\hline $\begin{array}{l}\text { Kondisi cuaca } \\
\text { berubah-ubah }\end{array}$ & 0,08108 & 2 & 0,16216 \\
\hline $\begin{array}{l}\text { Tingginya daya } \\
\text { saing antar usaha } \\
\text { kerupuk }\end{array}$ & 0,06563 & 1 & 0,06563 \\
\hline $\begin{array}{l}\text { Munculnya } \\
\text { pesaing baru yang } \\
\text { meniual harga }\end{array}$ & 0,06949 & 2 & 0,13898 \\
\hline Total Ancaman & $30 \%$ & & 0,52121 \\
\hline Total EFAS & 1,00 & & 2,82229 \\
\hline
\end{tabular}

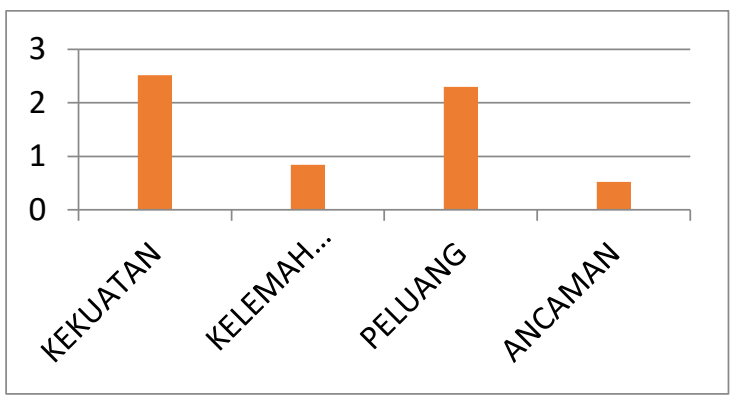

Gambar 2. Grarik Hasil Matriks IFAS dan EFAS

\section{Kesimpulan}

Berdasarkan hasil analisa dan pembahasan pada bab-bab sebelumnya, maka dapat disimpulkan beberapa point sebagai berikut:

1. Hasil selisih nilai kekuatan dan kelemahan adalah (+) 1,67184 dan selisih nilai peluang dan ancaman adalah (+) 1,77987, nilai tersebut menunjukkan bahwa organisasi mengalami suatu masa pertumbuhan, baik dalam penjualan, cita rasa, dan selisih harga.

2. UMKM Kerupuk Kemplang dua Putri berada pada kuadran pertama, yaitu kuadran strategy agresif. Dimana UMKM ini berada di posisi yang sangat menguntungkan, UMKM ini memiliki peluang dan kekuatan sehingga dapat memanfaatkan peluang yang ada.

3. Stategi yang harus diterapkan oleh UMKM dua putri adalah strategi yang mendukung kebijakan pertumbuhan yang agresif (Growth Oriented Strategy). Yaitu strategi mengejar pertumbuhan ekonomi. Dari peluang dan kekuatan tersebut UMKM Dua Putri bisa memanfaatkannya sehingga dapat meningkatkan loyalitas pelanggan.

\section{Daftar Pustaka}

Akbar, E. (2014). Analisis Strategi Pemasaran Sarinira Hot Chocolate Dengan Metode BCG, SWOT, dan Benchmarking (Studi Kasus : CV. Sarinira Nusantara). Skripsi. Dipublikasi : Universitas Muhammadiyah Surakarta

Alamsyah N. (2019). Analisis Stratgi Pemasaran Perusahaan Supplier Kusen Aluminium Dengan Metod SWOT (Studi Kasus Di CV. Pillar Jaya Sentosa). Jurnal Kreatif Industri. Vol.3 No. 1 ISSN : 2597-8950. Teknik Industri STT Ibnu Sina . Batam.

Anoraga, Pandji, (2016), Manajemen Bisnis, Edisi Kedua, Rineka Cipta, Jakarta.

Basu Swastha dan. (2002). Manajemen Pemasaran Modern. Yogyakarta : Liberty

Fajar kuniawan. (2017). SWOT Analysis (Analisis SWOT) - Manajemen Pemasaran-Marketing. https://www.youtube.com/channel/UCFUY A3JTcLXKj34HcKpVA1w

Fandy Tjiptono. 2014. Pemasaran Jasa (Prinsip, Penerapan, Penelitian). Yogyakarta. Andi.

Farah, Dinnia Ainul. 2018. Analisis SWOT Dalam Menentukan Strategy Competitive Advantage Pada Pusat Souvenir (Studi Kasus CV Nabata Souvenir Desa Kendalrejo Kecamatan Talun Kabupaten Blitar. Tulungagung: Institut Agama Islam Negeri Tulungagung 
Friesner, (2010). Analisis swot. diproleh di https://id.wikipedia.org/wiki/Analisis_SWO $\mathrm{T}$

Indra mustofa. (2020). Cara mudah belajar tentang jenis sampel dalam penelitian kuantitatif. https://www.youtube.com/watch?v=wvfcp VJIP8A

Jazuli, Syauqi. 2016. Analisis SWOT Strategi Pemasaran Produk Pembiayaan Pada BMT EL-SYIFA Ciganjur. Jakarta: Universitas Islam Negeri Syarif Hidayatullah Jakarta

Kotler, Philip and Gary Amstrong. (2016). Prinsipprinsip Pemasaran. Edii13. Jilid 1. Jakarta:Erlangga.

Mifthahurizal K. (2017). Analisis Strategi Pengembangan Usaha Minuman Sari Buah Sirsak. Jurnal Teknologi Dan Manajemen Agroindustri. Vol. 6. No. 2. ISSN 22527877. Faculty Of Agricultural Teclology. Universitas Brawijaya. Malang

Moh. Zainal.A.(2017). Pemilihan Strategi Pemasran Dngan Metode SWOT Dan TOPSIS. Jurnal Teknik Industri Vo. 18. No. 01. ISSN 1978-1431. Fakultas Teknik. Universitas Muhammadiyah Malang. Jawa Timur.

Moleong, Lexy J. (2012). Metodologi Penelitian Kualitatif. Bandung : PT Remaja Rosdakarya.

Nova W. (2018). Analisis Swot Produk Teh Wangi Pada PT. NSP. JITMI Vol.1 . No.2 Teknik Industri Universitas Pemulang. Pemulang.

Pebrian Adi W.(2019). Analisis strategi pemasaran untuk meningkatkan penjualan engan menggunakan analisis swot pada CV. RJM. Prosiding Semnas Teknik UMAHA, ISSN 2721-2662. Teknik Industri Universitas Maarif Hasym Latif, Sidoarjo.

Purnomo, Yusnowo Hadi, (2018). Analisis Swot Dan Stratgi Pemasaran Untuk Meningkatkan Daya Saing UKM Es Puter Di Kota Malang. Jurnal Teknologi, Informasi, Dan Industri, Vol I, N0 1. Teknik Industri universitas Ma Chung .Malang

Rangkuti, Fredy, (2016). Teknik Membedah Kasus Bisnis Analisis SWOT. Gramedia: Jakarta

Riski Amalia, Nina Hairiah. (2019). Strategi Pemasaran Produk Bepang UD. Cap Bunga Kecamatan Palaihari Kabupaten Tanah Laut. Jurnal Teknologi Agro-Inustri Vol.6 No 1. E-ISSN 2598-5884. Teknologi
Industri Pertanian, Politeknik Negeri Tanah Laut. Kalimantan Selatan.

Sara Ramadona. (2018). Analisis Strategi Pemasaran Produk Keripik UD. Bagus Abadi Jaya Menggunakan Metode SWOT. Teknik Industri Universitas Muhammadiyah Gresik. Gresik.

Syahnur. M. Akbar. (2015). Analisa Strategi Pemasaran Terhadap Performance Kerja Dngan Menggunakan Metode Analisis SWOT.Seminar Nasional Teknologi Industri Ratih Vol. 1. Edisi 1. ISSN 2407-8670. Teknik Industri Universitas Mercu Buana. Jakarta Barat

Sunarti. (2009). Metode-metode Penelitian. Bandung: Alfabeta.

Tambunan, Tulus, (2009). Usaha Mikro Kecil Dan Menengah Di Indonesia : Isu-Isu Penting. LP3ES. Jakarta

Widiarini. Z. F. (2019). Perencanaan Strategi Pemasaran Mengunakan Analisis SWOT Dan QSPM Dalam Upaya Peningkatan Penjualan PT Primavista Solusi. Jurnal Of Aplied Business And Economis Vol.5. No. 4. ISSN 384-397. Teknik Industri Universitas Indraprasta PGRI. Indaraprasta 